\title{
The Efficacy of Supportive Peri-Implant Therapies in Preventing Peri-Implantitis and Implant Loss: a Systematic Review of the Literature
}

\author{
Ausra Ramanauskaite ${ }^{1}$, Tellervo Tervonen ${ }^{2,3}$ \\ ${ }^{1}$ Department of Dental and Oral Pathology, Lithuanian University of Health Sciences, Lithuania. \\ ${ }^{2}$ Department of Periodontology and Geriatric Dentistry, Unit of Oral Health Sciences, University of Oulu, Finland. \\ ${ }^{3}$ Medical Research Center Oulu (MRC Oulu), University of Oulu and Oulu University Hospital, Finland.
}

\author{
Corresponding Author: \\ Tellervo Tervonen \\ Department of Periodontology and Geriatric Dentistry, Unit of Oral Health Sciences \\ University of Oulu \\ P.O. Box 8100, FI-90014 University of Oulu \\ Finland \\ E-mail: tellervo.tervonen@oulu.fi
}

\begin{abstract}
Objectives: To study the efficacy of supportive peri-implant therapies in preventing clinical and radiological signs of periimplantitis and implant loss.

Material and Methods: Longitudinal human studies, published between January 1, 2006, and February 1, 2016, were included based on an electronic search using MEDLINE and EMBASE databases and complemented by a manual search. Articles were included only if 1) they comprised a group of patients involved in/adhering to regular supportive peri-implant therapies (SPTs) and a control group without such therapies or with poor adherence to them, 2) the protocol of the SPTs was clearly described and 3 ) the outcome was indicated by means of clinical/radiological changes or implant loss.

Results: After initially identifying a total of 710 titles and abstracts, 12 full text articles were selected for eligibility assessment. Seven studies, three prospective and four retrospective, fulfilled the inclusion criteria for this review.

The frequency of recall visits varied between the studies from a minimum of one visit every three months to an individually tailored regimen. In all the studies a lack of SPTs or poor adherence to them resulted in significantly higher frequencies of sites with mucosal bleeding, deepened peri-implant pockets or alveolar bone loss. In line with the above, a lack of/poor adherence to SPTs was associated with higher implant loss.

Conclusions: To prevent peri-implantitis, an individually tailored supportive programme based on patient motivation and reinstruction in oral hygiene measures combined with professional implant cleaning seem to be crucial.
\end{abstract}

Keywords: compliance; dental implant; maintenance; peri-implantitis.

Accepted for publication: 19 August 2016

To cite this article:

Ramanauskaite A, Tervonen T.

The Efficacy of Supportive Peri-Implant Therapies in Preventing Peri-Implantitis and Implant Loss: a Systematic Review of the Literature

J Oral Maxillofac Res 2016;7(3):e12

URL: http://www.ejomr.org/JOMR/archives/2016/3/e12/v7n3e12.pdf

doi: 10.5037/jomr.2016.7312 


\section{INTRODUCTION}

Despite the overall satisfactory survival rates of dental implants [1], it is well known that a proportion of implants are unsuccessful due to various inflammatory pathoses in peri-implant tissues. These include two main disease entities: peri-implant mucositis, which is a condition limited to the mucosa surrounding the implant, and peri-implantitis, characterised by a loss of peri-implant bone [2]. In the recent $11^{\text {th }}$ European Workshop on Periodontology consensus conference, weighted mean prevalences of $43 \%$ and $22 \%$ of periimplant mucositis and peri-implantitis, respectively, were reported [3] . Both animal and human studies have provided evidence that the primary aetiologic factor in peri-implant inflammation is accumulation of plaque around the mucosal margins of implants $[\underline{4}, \underline{5}]$, as is the case in gingivitis of natural teeth. To confirm the biofilm-related aetiology of peri-implant inflammation, several studies have shown that, subsequent to plaque removal, resolution of periimplant mucositis is evident [ $\underline{-5-7]}$.

It is generally agreed that gingivitis of natural teeth and peri-implant mucositis of implants are precursors of their advanced forms, periodontitis and periimplantitis, respectively [ㅁ]. Therefore, prevention and management of peri-implant mucositis are critical in long-term maintenance of implants. While no studies on primary prevention of peri-implant mucositis are available, it is evident from recent systematic reviews and meta-analyses that a reduction in clinical signs of peri-implant inflammation is possible after patient-performed [9] or professional [10] plaque control. Of note is, however, that complete resolution of inflammation cannot be achieved in all patients.

Hultin et al. [11] studied whether supportive treatment is effective in the prevention of biological complications of implant therapy and fixture loss. The review was based on nine studies of 749 implants at a 10-year examination. In only two of the reviewed studies the patients were enrolled in an individualised maintenance programme; in the remaining studies the treatment provided at the recall visits was not reported. Therefore, the group called for new studies to suggest the frequency of recall visits and to propose specific hygiene treatments. A later systematic review and meta-analysis [12], based on qualitative and quantitative analyses of 13 and 10 studies, respectively, assessed the impact of supportive maintenance therapies on peri-implant conditions. This review showed a positive effect of the therapies, and the authors recommended implementation of a maintenance programme after implant placement and restorative treatment.

Although biological complications associated with dental implants cannot be completely avoided, it is likely that the overall long-term success of implant therapy can be improved by the establishment of supportive peri-implant therapies (SPTs) [9, 12]. While the $11^{\text {th }}$ European Workshop on Periodontology consensus conference focused on the efficacy of preventive measures in managing peri-implant mucositis, only scarce evidence of the effectiveness of supportive therapies in managing biological complications beyond mucositis is available. Therefore, we conducted a systematic review of the literature to study the efficacy of SPTs on periimplantitis-associated clinical and radiologic signs and implant loss.

\section{MATERIAL AND METHODS Protocol and registration}

The methods of the analysis and inclusion criteria were specified in advance and documented in a protocol. The review was registered in PROSPERO, an international prospective register of systematic reviews. The protocol can be accessed at: http://www.crd.york.ac.uk/PROSPERO/display record.asp?ID=CRD42016035621

The reporting of this systematic analysis adhered to the Preferred Reporting Items for Systematic Review and Meta-Analyses (PRISMA) Statement [13].

\section{Focus question and outcomes}

The following focus question was developed according to the population, intervention, comparison and outcome (PICO) study design:

- What is the efficacy of supportive peri-implant therapies evaluated by means of clinical (bleeding and/or probing depth) and/or radiological (marginal bone level) changes around dental implants and/or implant loss for patients with osseointegrated dental implant(s)?

- Primary outcome: occurrence of various signs of peri-implantitis (peri-implant bleeding/deepened peri-implant pockets/peri-implant bone loss).

- Secondary outcome: implant loss/survival.

\section{Information sources}

The search strategy incorporated an examination of the electronic database Scopus, which covers the whole MEDLINE database (Ovid) and a greater 
part $(90 \%)$ of the EMBASE database. Additionally, a manual search was conducted in the following journals: "Clinical Oral Implants Research", "Implant Dentistry", "International Journal of Oral \& Maxillofacial Implants", "International Journal of Periodontics and Restorative Dentistry", "Journal of Clinical Periodontology" and "Journal of Periodontology".

The references of each relevant study were screened to find additional relevant publications and to improve the sensitivity of the search.

\section{Search}

The keywords and search inquiries used during the primary stage were: ("implant loss" OR "implant survival" OR "peri-implantitis" OR periimplantitis OR "peri-mucositis" OR perimucositis OR "periimplant mucositis" OR "periimplant mucositis" OR "biological complication") AND ("prevention" OR "maintain" OR "maintenance" OR "support" OR "supportive therapy"). The choice of keywords was intended to be broad to collect as much relevant data as possible without relying on electronic means alone to refine the search results.

\section{Selection of studies}

The review included all human prospective or retrospective follow-up studies (clinical trials, cohort studies and case-control studies) in the English language published between January 1, 2006, and February 1, 2016.

Titles and abstracts derived from this broad search were independently screened by both authors to eliminate irrelevant publications (Figure 1). The final stage of screening involved reading the full texts to confirm each study's eligibility based on the inclusion criteria below.

\section{Inclusion criteria}

Studies were included in this review only if they met the following inclusion criteria:

- The subjects must have had at least one osseointegrated dental implant;

- A group of subjects involved in/adhering to regular SPTs and a control group without such therapies or with poor adherence were included;

- The protocol of the supportive peri-implant therapy was clearly described;

- The efficacy of supportive peri-implant therapy was evaluated by means of clinical (plaque, bleeding and/or probing depth scores) and/or radiological (marginal bone level) changes around dental implant(s), and/or implant loss at the end of the follow-up period.

The following types of articles were excluded: letters, editorials, theses, commentaries, consensus statements, reviews and meta-analyses. Furthermore, animal and in vitro studies were excluded. In case of unclear data, the authors were contacted to obtain the data.

\section{Data extraction and data items}

The data were independently extracted from the studies according to the aims and themes of the present review as follows (Table 1):

- "Author" - revealed the authors of the study and the year of publication.

- "Study design and follow-up" - revealed the type of study and the time period in months/years during which the patients in the test and control groups were followed.

- "Population" - revealed the size and characteristics of the study population.

- "Test group" - revealed the regimen of SPTs applied and the numbers of patients and implants (if available).

- "Control group" - revealed the numbers of patients and implants (if available) included.

- "Results" - described the efficacy of supportive peri-implant therapies evaluated by means of clinical (bleeding on probing and/or probing depth) and/or radiological (bone level) changes around dental implant(s), and/or implant loss.

Due to great heterogeneity in the methodologies (aims, outcomes, study populations, treatment protocols) between the included studies we preferred a qualitative analysis and a quantitative data synthesis for meta-analysis was not considered.

\section{Assessment of methodological quality}

The quality of all included studies was assessed during the data extraction process and involved evaluating the methodological elements that might influence the outcome of each study (Table 2). The Cochrane Collaboration's two-part tool for assessing risk of bias [14] was used to assess bias across the studies and to identify papers with intrinsic methodological and design flaws. Based on the information given in each study the potential risk of bias was categorized into 'low', 'unclear' or 'high' by one of the authors (AR). 
Table 1. Descriptive information of the included studies

\begin{tabular}{|c|c|c|c|c|c|c|c|}
\hline Author & $\begin{array}{c}\text { Year of } \\
\text { publication }\end{array}$ & Study design & Follow-up & Population & Test group & Control group & Results \\
\hline Anner et al. [20] & 2010 & $\begin{array}{l}\text { Retrospective } \\
\text { study }\end{array}$ & $1-114$ months & $\begin{array}{l}475 \text { patients } \\
1626 \text { implants }\end{array}$ & $\begin{array}{c}\text { Patients participating in recall visits for oral hygiene instruction and re- } \\
\text { enforcement as well as professional cleaning every } 3-6 \text { months. } \\
\text { (246 patients; } 873 \text { implants) }\end{array}$ & $\begin{array}{l}\text { Patients who only attended } \\
\text { annual free-of-charge implant } \\
\text { examinations. } \\
\text { (229 patients; } 753 \text { implants) }\end{array}$ & $\begin{array}{l}\text { The proportion of patients with failed implants ( } \mathrm{P}=0.0114 \text { ) and the frequency } \\
\text { of failed implants }(\mathrm{P}=0.0028 \text { ) were lower in patients attending a structured } \\
\text { SPT programme. } \\
\text { Patients not attending a SPT had an OR of } 1.89 \text { for implant failure. }\end{array}$ \\
\hline Costa et al. [21] & 2012 & $\begin{array}{l}\text { Retrospective } \\
\text { study }\end{array}$ & 5 years & $\begin{array}{l}80 \text { PHP and PCP } \\
\text { diagnosed with } \\
\text { peri-implant } \\
\text { mucositis }\end{array}$ & $\begin{array}{l}\begin{array}{l}\text { Patients with preventive maintenance (GTP group): at least five dental } \\
\text { visits during the } 5 \text {-year evaluation period. During the visits periodontal } \\
\text { and peri-implant status assessment was performed. } \\
\text { Oral hygiene instructions and mechanical debridement, when needed. } \\
\text { (39 patients; } 156 \text { implants) }\end{array} \\
\end{array}$ & $\begin{array}{l}\text { No maintenance (GNTP group). } \\
\text { (41 patients; } 180 \text { implants). }\end{array}$ & $\begin{array}{l}\text { The incidence rates of peri-implantitis observed in the GTP group }(18 \%) \text { were } \\
\text { significantly lower than those observed in the GNTP group }(44 \%)(\mathrm{P}<0.01) \text {. } \\
\text { Absence of maintenance was associated with a higher incidence of peri- } \\
\text { implantitis. }\end{array}$ \\
\hline Fricsh et al. [22] & 2014 & $\begin{array}{l}\text { Retrospective } \\
\text { study }\end{array}$ & 3 years & $\begin{array}{l}236 \text { PHP and PCP } \\
540 \text { implants }\end{array}$ & 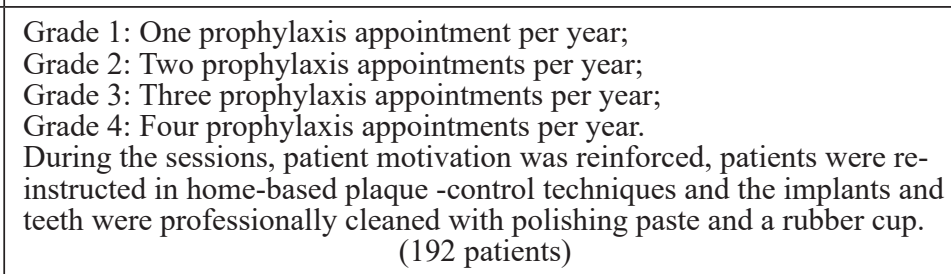 & $\begin{array}{l}\text { Grade 0: No prophylaxis } \\
\text { appointments per year; } \\
\text { Grade 00: patients without } \\
\text { any appointment in the entire } \\
\text { observation period. } \\
\text { (44 patients) }\end{array}$ & $\begin{array}{l}\text { A significant correlation between lower compliance and increased PPD was } \\
\text { detected }(P=0.032) \text {. } \\
3 \text {-month recalls recommended. }\end{array}$ \\
\hline Rinke et al [23] & 2011 & $\begin{array}{l}\text { Retrospective } \\
\text { study }\end{array}$ & 68.2 (SD 24.8) months & $\begin{array}{l}89 \text { PHP and PCP } \\
540 \text { implants }\end{array}$ & $\begin{array}{l}\text { Regular prophylaxis (including re-instruction and re-motivation in } \\
\text { effective plaque control, professional tooth cleaning and polishing using } \\
\text { rubber cups and polishing paste and application of fluoride gel) every } \\
6 \text { months was performed in patients without a history of periodontal } \\
\text { disease, and SPT ( (uppoportive periodontal therapy) in patients with a } \\
\text { history of periodontal disease. } \\
\text { Subgingival scaling of implants using an ultrasonic tip and hand } \\
\text { instruments was performed is sites with } \mathrm{PD} \geq 5 \mathrm{~mm} \text {. } \\
\text { (58 patients) }\end{array}$ & $\begin{array}{l}\text { Irregular prophylaxis } \\
\text { (31 patients) }\end{array}$ & $\begin{array}{l}\text { Patients who did not participate in regular post-treatment programmes bore } \\
\text { an 11-fold higher chance of peri-implantitis than patients showing good } \\
\text { compliance }(\mathrm{OR}=0.09, \mathrm{Cl}=0.01 \text { to } 0.58, \mathrm{P}=0.011) \text {. }\end{array}$ \\
\hline Roccuzzo et al. [24] & 2010 & $\begin{array}{l}\text { Prospective } \\
\text { cohort study }\end{array}$ & 10 years & $\begin{array}{l}28 \text { PHP, } \\
37 \text { moderate PCP, } \\
36 \text { severe PCP } \\
246 \text { implants }\end{array}$ & $\begin{array}{l}\text { An individually tailored SPT including continuous evaluation, } \\
\text { motivation, reinstruction, instrumentation and treatment of re-infected } \\
\text { sites. The treatment of peri-implant biologic complications according to } \\
\text { CIST. } \\
\text { Recall intervals depending on the initial diagnosis and treatment results. } \\
\text { (79 patients) }\end{array}$ & 22 patients not adhering to SPTs & $\begin{array}{l}\text { - Moderate PCP: the number of patients with bone loss } \geq 3 \mathrm{~mm} \text { ( } \mathrm{P}=0.003 \text { ) or } \\
\text { implant loss (P=0.005) was higher among patients not adhering than in those } \\
\text { adhering to SPS; } \\
\text { - Severe PCP: the number of patients with implant loss was higher in subjects } \\
\text { not adhering than in those adhering to SPTs }(\mathrm{P}=0.016)\end{array}$ \\
\hline Roccuzzo et al. [25] & 2012 & $\begin{array}{l}\text { Prospective } \\
\text { cohort study }\end{array}$ & 10 years & $\begin{array}{l}28 \text { PHP, } \\
37 \text { moderate PCP, } \\
36 \text { severe PCP } \\
246 \text { implants }\end{array}$ & $\begin{array}{l}\text { An individually tailored SPT programme including continuous } \\
\text { evaluation, motivation, reinstruction, instrumentation and treatment of } \\
\text { re-infected sites. } \\
\text { The treatment of peri-implant biologic complications according to CIST. } \\
\text { Recall intervals depending on the initial diagnosis and treatment results. } \\
\text { (79 patients) }\end{array}$ & 22 patients not adhering to SPT & $\begin{array}{l}\text { Compared with patients adhering to SPTs, at } 10 \text { years those not adhering had: } \\
\text { - In moderate } \mathrm{PCP} \text { : a significantly higher proportion of sites with } \mathrm{BOP}(\mathrm{P}) \\
=0.0001) \text {, greater mean deepest } \mathrm{PD}(\mathrm{P}=0.0001) \text { and higher proportions of } \\
\text { implants with deepest } \mathrm{PD} \geq 6 \mathrm{~mm}(\mathrm{P}=0.001) ; \\
- \text { In severe } \mathrm{PCP} \text { : a significantly higher proportion of sites with } \mathrm{BOP} \text { ( } \mathrm{P}= \\
0.0006) \text {, greater mean deepest } \mathrm{PD}(\mathrm{P}=0.009) \text {, higher proportions of implants } \\
\text { with } \mathrm{PD} \geq 6 \mathrm{~mm}(\mathrm{P}=0.01) \text {. }\end{array}$ \\
\hline Roccuzzo et al. [26] & 2014 & $\begin{array}{l}\text { Prospective } \\
\text { cohort study }\end{array}$ & 10 years & $\begin{array}{l}32 \text { PHP, } \\
46 \text { moderate PCP, } \\
45 \text { severe PCP } \\
252 \text { implants }\end{array}$ & $\begin{array}{l}\text { An individually tailored SPT programme including continuous } \\
\text { evaluation, reinstruction, instrumentation and treatment of re-- } \\
\text { infected sites. The diagnosis and treatment of peri-implant biological } \\
\text { complications according to CIST. } \\
\text { (75 patients) }\end{array}$ & 48 patients not adhering to SPT & $\begin{array}{l}\text { Compared with patients adhering to } \mathrm{SPTS} \text {, at } 10 \text { years those not adhering had: } \\
\text { - In moderate } \mathrm{PCP} \text { : a higher proportion of sites with } \mathrm{BOP}(\mathrm{P}=0.018) \text {, greater } \\
\text { mean deepest } \mathrm{PD} \text { at implants }(\mathrm{P}=0.02) \text { and higher frequency of implants with } \\
\text { at least one site with } \mathrm{PD} \geq 6 \mathrm{~mm}(\mathrm{P}<0.001) \\
\text { - In severe } \mathrm{PCP} \text { : greater mean deepest } \mathrm{PD}(\mathrm{P}=0.01) \text {, higher frequency of } \\
\text { implants with a least one site with } \mathrm{PD} \geq 6 \mathrm{~mm}(\mathrm{P}=0.001) \text { and higher number } \\
\text { of lost teeth }(\mathrm{P}=0.03) \text {. }\end{array}$ \\
\hline
\end{tabular}

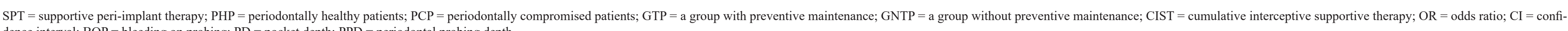
dence interval; $\mathrm{BOP}=$ bleeding on probing; $\mathrm{PD}=$ pocket depth; $\mathrm{PPD}=$ periodontal probing depth.

Table 2. Assessment of the risk of bias

\begin{tabular}{l|c|c|c|c|c|c}
\hline \multicolumn{1}{c|}{ Author } & $\begin{array}{c}\text { Random sequence } \\
\text { generation }\end{array}$ & $\begin{array}{c}\text { Allocation } \\
\text { concealment }\end{array}$ & Blinding & $\begin{array}{c}\text { Incomplete } \\
\text { outcome data }\end{array}$ & $\begin{array}{c}\text { Selective } \\
\text { reporting }\end{array}$ & $\begin{array}{c}\text { Other } \\
\text { bias }\end{array}$ \\
\hline Anner et al. [20] & $?$ & $?$ & - & + & $?$ & + \\
\hline Costa et al. [21] & $?$ & $?$ & $?$ & - & $?$ & + \\
\hline Frisch et al. [22] & $?$ & $?$ & $?$ & - & $?$ & + \\
\hline Rinke et al. [23] & $?$ & $?$ & $?$ & + & $?$ & + \\
\hline Roccuzzo et al. [24] & $?$ & $?$ & + & + & $?$ & + \\
\hline Roccuzzo et al. [25] & $?$ & $?$ & + & + & $?$ & + \\
\hline Roccuzzo et al. [26] & $?$ & $?$ & + & + & $?$ & + \\
\hline
\end{tabular}

$+=$ low risk; ? = unclear risk; - = high risk. 


\section{RESULTS}

\section{Search results}

The article review and data extraction were performed according to the PRISMA flow diagram (Figure 1). The initial database search displayed 716 results and one result was obtained from the manual search. Abstracts were available for 710 articles. Preliminary exclusion was done by relevancy; 51 non-relevant titles and abstracts were excluded. Of the remaining 659 results, 17 case reports and 65 systematic reviews or meta-analyses were further filtered.
After exclusion of abstracts $(n=566)$ that did not include information on the selected topic, 12 full text articles were assessed for eligibility. Another exclusion was done because information on the SPT regimen was not available [15] or because there was no control group [16-19]. Finally, seven articles were included in the review (Figure 1).

\section{Description of the included studies}

Anner et al. [20] evaluated the influence of SPT on long-term implant survival in a retrospective study of 475 patients with 1626 inserted implants.

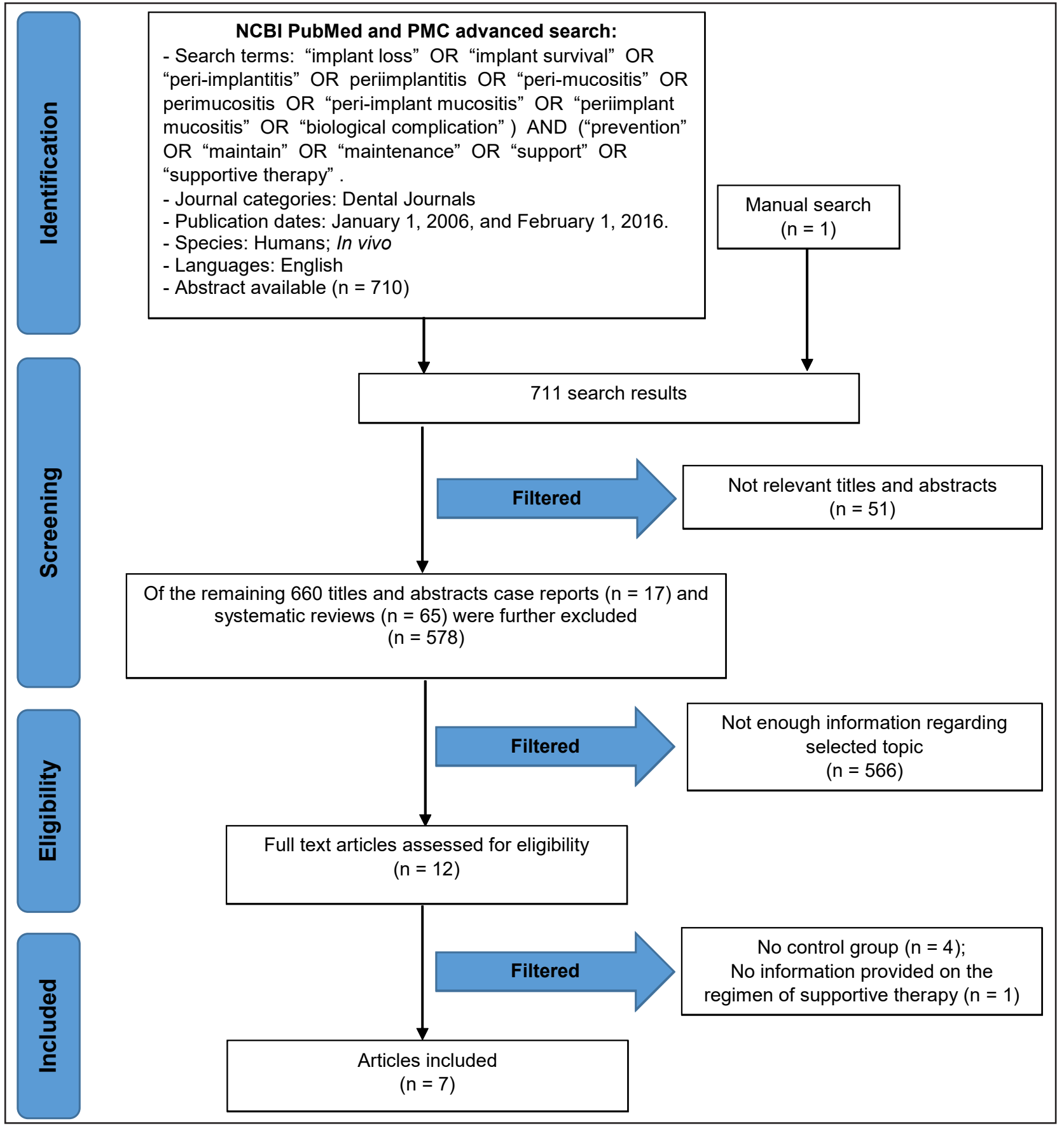

Figure 1. PRISMA flow diagram. 
According to personal communication with the authors, the SPT regimen included oral hygiene instruction and re-enforcement as well as professional cleaning every 3 - 6 months. Overall, 77 implants $(4.7 \%)$ were lost in 58 patients $(12.2 \%)$. Patients not attending the SPT programme had an odds ratio of 1.89 for implant failure.

The outcome of a five-year retrospective study by Costa et al. [21] highlighted the importance of SPT in preventing the onset of peri-implantitis. The frequency of maintenance visits was at least one visit per year. After being diagnosed with peri-implant mucositis, $18 \%$ of the subjects enrolled in SPT progressed to peri-implantitis, while the incidence of peri-implantitis amounted to $44 \%$ in subjects without SPT. The lack of preventive maintenance within the overall sample was significantly associated with peri-implantitis in a logistic model (OR = 5.92). The authors highlight the necessity of preventive maintenance and continuous monitoring of clinical peri-implant parameters when mucositis is present.

A retrospective study by Frisch et al. [22] evaluated patient compliance to supportive post-implant therapy (SIT) over a three-year period. The yearly assessed compliance rate, which was categorised into five grades, ranged from four prophylaxis appointments per year to no compliance to prophylaxis at all. This study revealed high rates of patient compliance (86 $94 \%$ ) to a SIT programme over the first three years. A significant correlation was found between lower compliance and increased pocket probing depth $(P=0.032)$. In addition, higher plaque rates were found in individuals with lower compliance rates $(P=0.087)$. However, the results of the study did not reveal a statistically significant correlation between compliance and peri-implant tissue inflammation (BOP+ values).

The prevalence rates of peri-implant mucositis and peri-implantitis were evaluated by Rinke et al. [23] in 89 patients, who were classified into being on 'regular prophylaxis/SPT' (those who did not exceed the recommended intervals for prophylaxis/SPT by more than $100 \%$ ) and 'irregular prophylaxis/SPT' (patients who exceeded the recommended interval at least once by more than $100 \%$ ). Prophylaxis (in patients without a history of periodontitis) and SPT (in patients with a history of periodontitis) were rendered to most patients at three-month intervals during the first year after implant placement and later on at six-month intervals. Based on the finding of this study, patients who did not participate in regular post-treatment programmes bore an 11-fold higher chance of periimplantitis than patients showing good compliance $(\mathrm{OR}=0.09 ; \mathrm{CI}=0.01$ to $0.58 ; \mathrm{P}=0.011)$.
The long-term outcomes of implant therapies in relation to adhesion to SPTs were studied in threearm prospective cohort studies by Roccuzzo and co-authors [24-26]. Implants were placed at the end of periodontal therapy and the outcomes of the treatment were evaluated during the SPTs and at 10 years. Based on their initial periodontal status, the patients were divided into periodontally healthy (PHP) and either moderately or severely periodontally compromised patients (PCP), and the treatment outcomes were measured as presence of plaque, bleeding on probing, probing pocket depth, peri-implant bone loss, treatment need according to CIST (interceptive supportive therapy) principle and implant loss. In periodontally healthy patients, no statistically significant differences in any of the periodontal variables were observed between patients adhering and not adhering to SPTs at 10 years. In the moderately and severely compromised groups, lack of adhesion to SPTs was associated with higher plaque and bleeding scores, deeper probing pocket depths both during the SPTs and at 10 years and a higher frequency of implant loss. In addition, a tendency of a higher need for antibiotic and surgical implant therapies was reported in the group of patients not adhering to SPTs [26].

\section{Risk of bias within studies}

Summarising the risk of bias for each study, all the studies were judged to have an unclear risk (of bias in more than one domain) (Table 2).

\section{DISCUSSION}

All the studies in the current review reported a significant positive effect of SPTs on peri-implant conditions. In addition, it became evident that periimplant mucositis, if left untreated, may progress to peri-implantitis. In all the studies the preventive programmes comprised re-instruction/re-enforcement of oral home care and professionally performed prophylaxis or mechanical debridement/submucosal scaling of implant surfaces. Thus, the main conclusion drawn from this review is that providing such treatments for every patient after surgical and prosthetic phases is crucial to improving the long-term success of implant therapy.

Based on a qualitative analysis of 13 studies, Monje et al. [12] likewise concluded that peri-implant maintenance therapy is needed 'to potentially prevent biological complications and hence heighten the long-term success rate' of implant therapy. 
While studies clearly reporting the frequency of periimplant maintenance therapy were included in their qualitative analysis, we required, in addition, that the included studies also reported the protocol of the SPTs and had a control group.

The primary question in this systematic review was 'To what extent can peri-implantitis be prevented by SPTs?' Thus, we focused on prevention of inflammatory changes beyond peri-implant mucositis, which, according to the recent consensus by the $11^{\text {th }}$ European Workshop of Periodontology consensus conference, was found to be largely preventable [9]. The advanced biological complications, periimplantitis and implant loss, can be considered endpoints in the continuum from healthy peri-implant tissues to loss of peri-implant bone via inflammation of mucosal soft tissues (peri-implant mucositis) and deepening of peri-implant pockets. Overall, three studies in this review related a lack of/poor adherence to SPTs to deepening of peri-implant pockets [24-26], two studies to peri-implantitis $[\underline{21}, \underline{23}]$, two studies to peri-implant bone loss $[\underline{21}, 24]$ and two studies to implant loss $[\underline{20}, \underline{24}]$. Albeit deepened peri-implant pockets 'per se' have not been considered diagnostic criteria for peri-implantitis by prominent authorities $[\underline{8}, \underline{27}, \underline{28}]$, we used, parallel with many studies $[\underline{29}, \underline{30}]$, deepened peri-implant pockets as one of the clinical end-points in this review. Generally speaking, it is not precisely known how valid as tools the clinical measures adopted from studies of natural teeth (for example bleeding on probing, probing pocket depth and clinical attachment level) are for studies of periimplant diseases $[\underline{29}, \underline{30}]$.

The benefits of supportive therapies in long-term maintenance of natural teeth have been shown in several studies $[\underline{31}, \underline{32}]$. As for periodontal diseases, prevention of peri-implant diseases should be tailored according to each individual's needs through diagnosis and risk profiling [33-35]. In daily practice this means monitoring/diagnosing peri-implant conditions, motivating and educating the patient in oral self-care, professional mechanical plaque removal and, if manageable, control of risk factors. In the reviewed studies a few important risk factors such as smoking, susceptibility to periodontitis/ periodontal disease history, diabetes and greater geographic distances to the study centre were recognised. An important finding here was that even under 'state-of-the-art' SPTs, peri-implantitis occurred/progressed in some patients, more often in those with compromised periodontal condition [24-26].

The risk profile of the patient is an important element in determining the recall interval of the SPTs. In three of the reviewed studies the interval varied between 3 to 6 months $[20,22,23]$ and in the Roccuzzo studies [24-26] the treatment was delivered according to individual needs. In the Costa et al. study [21] the patients had a minimum of five visits during the five-year follow-up period. Monje et al. [12] made an attempt to define a 'reasonable' recall interval in preventing peri-implant infections and ended up with 5 - 6 months. The authors emphasised, however, that the maintenance therapy should in any case be customised according to the patients' risk profiling.

Unlike Hultin et al. [11], who selected studies presenting long-term clinical outcomes of ten years and more for their review, no restrictions were made here with regard to the length of the follow-up period. The positive effects of SPTs, verified as significantly decreased rates of peri-implant inflammation or bone loss, were evident already at five [21] or six [23] years, or during the course of the 10-year SPT as in the Roccuzzo studies [24-26]. Both human and animal studies show that the progression of an inflammatory lesion subsequent to plaque accumulation is more aggressive and the resolution of inflammation is slower at implant sites than at tooth sites $[4,5]$. Therefore, it is imperative that continuous monitoring of peri-implant health and preventive practices be started as a continuum to the prosthetic phase of the implant therapy.

\section{Limitations}

All the studies included in this review were judged to be of unclear risk of bias, which, according to the Cochrane Collaboration's tool, is sufficient to affect the interpretation of the results [14]. The limitations, to mention here a few, should therefore be considered when applying the results of this review to daily implant practices. Generally taken, it is unethical to leave patients with progressing peri-implant infections untreated, and therefore no 'golden standard' type of controlled/randomised controlled trials related to prevention can be performed. A majority of the included studies were retrospective by design and originally not intended to specifically assess the efficacy of preventive therapies on peri-implant infections. Moreover, many of the studies had small sample sizes and were therefore likely underpowered. In six studies the patients were recruited from private clinics specialised in periodontal or implant therapies and in one study from private and university clinics; caution should therefore be exercised in generalising the results to the population level. 


\section{CONCLUSIONS}

In light of the microbial aetiology of peri-implant infections, supportive peri-implant therapies targeting the removal of infectious agents at implant sites are needed. Within the limitations of the present systematic review, it can be concluded:

1. A lack of poor adherence to supportive periimplant therapies results in significantly higher frequencies of sites with mucosal inflammation and peri-implant bone loss as well as more frequent implant loss.
2. Individually tailored supportive peri-implant therapies based on patient motivation and reinstruction in oral hygiene measures combined with professional implant cleaning should be an integral part of implant therapy.

\section{ACKNOWLEDGMENTS AND DISCLOSURE STATEMENTS}

The authors have no conflicts of interest to disclose. The study was self-funded.

\section{REFERENCES}

1. Berglundh T, Persson L, Klinge B. A systematic review of the incidence of biological and technical complications in implant dentistry reported in prospective longitudinal studies of at least 5 years. J Clin Periodontol. 2002;29 Suppl 3:197212; discussion 232-3. [Medline: 12787220] [doi: 10.1034/j.1600-051X.29.s3.12.x]

2. Zitzmann NU, Berglundh T. Definition and prevalence of peri-implant diseases. J Clin Periodontol. 2008 Sep; 35(8 Suppl):286-91. [Medline: 18724856] [doi: 10.1111/j.1600-051X.2008.01274.x]

3. Derks J, Tomasi C. Peri-implant health and disease. A systematic review of current epidemiology. J Clin Periodontol. 2015 Apr;42 Suppl 16:S158-71. [Medline: 25495683] [doi: 10.1111/jcpe.12334]

4. Ericsson I, Berglundh T, Marinello C, Liljenberg B, Lindhe J. Long-standing plaque and gingivitis at implants and teeth in the dog. Clin Oral Implants Res. 1992 Sep;3(3):99-103. [Medline: 1290796] [doi: 10.1034/j.1600-0501.1992.030301.x]

5. Salvi GE, Aglietta M, Eick S, Sculean A, Lang NP, Ramseier CA. Reversibility of experimental peri-implant mucositis compared with experimental gingivitis in humans. Clin Oral Implants Res. 2012 Feb;23(2):182-90. [Medline: 21806683] [doi: 10.1111/j.1600-0501.2011.02220.x]

6. Porras R, Anderson GB, Caffesse R, Narendran S, Trejo PM. Clinical response to 2 different therapeutic regimens to treat peri-implant mucositis. J Periodontol. 2002 Oct;73(10):1118-25. [Medline: 12416768] [doi: 10.1902/jop.2002.73.10.1118]

7. Ji YJ, Tang ZH, Wang R, Cao J, Cao CF, Jin LJ. Effect of glycine powder air-polishing as an adjunct in the treatment of peri-implant mucositis: a pilot clinical trial. Clin Oral Implants Res. 2014 Jun;25(6):683-9. [Medline: 23432642] [doi: 10.1111/clr.12123]

8. Lang NP, Berglundh T; Working Group 4 of Seventh European Workshop on Periodontology. Periimplant diseases: where are we now?--Consensus of the Seventh European Workshop on Periodontology. J Clin Periodontol. 2011 Mar;38 Suppl 11:178-81. [Medline: 21323713] [doi: 10.1111/j.1600-051X.2010.01674.x]

9. Jepsen S, Berglundh T, Genco R, Aass AM, Demirel K, Derks J, Figuero E, Giovannoli JL, Goldstein M, Lambert F, Ortiz-Vigon A, Polyzois I, Salvi GE, Schwarz F, Serino G, Tomasi C, Zitzmann NU. Primary prevention of periimplantitis: managing peri-implant mucositis. J Clin Periodontol. 2015 Apr;42 Suppl 16:S152-7. [Medline: 25626479] [doi: $10.1111 /$ jepe. 12369 ]

10. Schwarz F, Becker K, Sager M. Efficacy of professionally administered plaque removal with or without adjunctive measures for the treatment of peri-implant mucositis. A systematic review and meta-analysis. J Clin Periodontol. 2015 Apr;42 Suppl 16:S202-13. [Medline: 25496187] [doi: 10.1111/jcpe.12349]

11. Hultin M, Komiyama A, Klinge B. Supportive therapy and the longevity of dental implants: a systematic review of the literature. Clin Oral Implants Res. 2007 Jun;18 Suppl 3:50-62. Review. Erratum in: Clin Oral Implants Res. 2008 Mar;19(3):326-8. [Medline: 17594370] [doi: 10.1111/j.1600-0501.2007.01447.x]

12. Monje A, Aranda L, Diaz KT, Alarcón MA, Bagramian RA, Wang HL, Catena A. Impact of Maintenance Therapy for the Prevention of Peri-implant Diseases: A Systematic Review and Meta-analysis. J Dent Res. 2016 Apr;95(4):372-9. [Medline: 26701350] [doi: 10.1177/0022034515622432]

13. Moher D, Liberati A, Tetzlaff J, Altman DG; PRISMA Group. Preferred reporting items for systematic reviews and metaanalyses: the PRISMA statement. Int J Surg. 2010;8(5):336-41. [Medline: 20171303] [doi: 10.1016/j.ijsu.2010.02.007]

14. Higgins JPT, Green S. Cochrane Handbook for Systematic Reviews of Interventions. The Cochrane Collaboration 2011. [URL: http://www.cochrane.org/cochrane-interventions-handbook]

15. Pjetursson BE, Helbling C, Weber HP, Matuliene G, Salvi GE, Brägger U, Schmidlin K, Zwahlen M, Lang NP. Peri-implantitis susceptibility as it relates to periodontal therapy and supportive care. Clin Oral Implants Res. 2012 Jul;23(7):888-94. [Medline: 22530771] [doi: 10.1111/j.1600-0501.2012.02474.x] 
16. Telleman G, Meijer HJ, Raghoebar GM. Long-term evaluation of hollow screw and hollow cylinder dental implants: clinical and radiographic results after 10 years. J Periodontol. 2006 Feb;77(2):203-10. [Medline: 16460245] [doi: 10.1902/jop.2006.040346]

17. Corbella S, Del Fabbro M, Taschieri S, De Siena F, Francetti L. Clinical evaluation of an implant maintenance protocol for the prevention of peri-implant diseases in patients treated with immediately loaded full-arch rehabilitations. Int J Dent Hyg. 2011 Aug;9(3):216-22. [Medline: 21356024] [doi: 10.1111/j.1601-5037.2010.00489.x]

18. Aguirre-Zorzano LA, Estefanía-Fresco R, Telletxea O, Bravo M. Prevalence of peri-implant inflammatory disease in patients with a history of periodontal disease who receive supportive periodontal therapy. Clin Oral Implants Res. 2015 Nov;26(11):1338-44. [Medline: 25132406] [doi: 10.1111/clr.12462]

19. Serino G, Turri A, Lang NP. Maintenance therapy in patients following the surgical treatment of peri-implantitis: a 5-year follow-up study. Clin Oral Implants Res. 2015 Aug;26(8):950-6. [Medline: 24861154] [doi: 10.1111/clr.12418]

20. Anner R, Grossmann Y, Anner Y, Levin L. Smoking, diabetes mellitus, periodontitis, and supportive periodontal treatment as factors associated with dental implant survival: a long-term retrospective evaluation of patients followed for up to 10 years. Implant Dent. 2010 Feb;19(1):57-64. [Medline: 20147817] [doi: 10.1097/ID.0b013e3181bb8f6c]

21. Costa FO, Takenaka-Martinez S, Cota LO, Ferreira SD, Silva GL, Costa JE. Peri-implant disease in subjects with and without preventive maintenance: a 5-year follow-up. J Clin Periodontol. 2012 Feb;39(2):173-81. [Medline: 22111654] [doi: 10.1111/j.1600-051X.2011.01819.x]

22. Frisch E, Ziebolz D, Vach K, Ratka-Krüger P. Supportive post-implant therapy: patient compliance rates and impacting factors: 3-year follow-up. J Clin Periodontol. 2014 Oct;41(10):1007-14. [Medline: 25138992] [doi: 10.1111/jepe.12298]

23. Rinke S, Ohl S, Ziebolz D, Lange K, Eickholz P. Prevalence of periimplant disease in partially edentulous patients: a practice-based cross-sectional study. Clin Oral Implants Res. 2011 Aug;22(8):826-33. [Medline: 21198898] [doi: 10.1111/j.1600-0501.2010.02061.x]

24. Roccuzzo M, De Angelis N, Bonino L, Aglietta M. Ten-year results of a three-arm prospective cohort study on implants in periodontally compromised patients. Part 1: implant loss and radiographic bone loss. Clin Oral Implants Res. 2010 May;21(5):490-6. [Medline: 20337668] [doi: 10.1111/j.1600-0501.2009.01886.x]

25. Roccuzzo M, Bonino F, Aglietta M, Dalmasso P. Ten-year results of a three arms prospective cohort study on implants in periodontally compromised patients. Part 2: clinical results. Clin Oral Implants Res. 2012 Apr;23(4):389-95. [Medline: 22092445] [doi: 10.1111/j.1600-0501.2011.02309.x]

26. Roccuzzo M, Bonino L, Dalmasso P, Aglietta M. Long-term results of a three arms prospective cohort study on implants in periodontally compromised patients: 10-year data around sandblasted and acid-etched (SLA) surface. Clin Oral Implants Res. 2014 Oct;25(10):1105-12. [Medline: 23865554] [doi: 10.1111/clr.12227]

27. Lindhe J, Meyle J; Group D of European Workshop on Periodontology. Peri-implant diseases: Consensus Report of the Sixth European Workshop on Periodontology. J Clin Periodontol. 2008 Sep;35(8 Suppl):282-5. [Medline: 18724855] [doi: $10.1111 /$ j.1600-051X.2008.01283.x]

28. The American Academy of Periodontology (AAP). Peri-implant mucositis and peri-implantitis: a current understanding of their diagnoses and clinical implications. J Periodontol. 2013 Apr;84(4):436-43. [Medline: 23537178] [doi: 10.1902/jop.2013.134001]

29. Faggion CM Jr, Listl S, Tu YK. Assessment of endpoints in studies on peri-implantitis treatment--a systematic review. J Dent. 2010 Jun;38(6):443-50. [Medline: 20226832] [doi: 10.1016/j.jdent.2010.03.003]

30. Graziani F, Figuero E, Herrera D. Systematic review of quality of reporting, outcome measurements and methods to study efficacy of preventive and therapeutic approaches to peri-implant diseases. J Clin Periodontol. 2012 Feb;39 Suppl 12:22444. [Medline: 22533959] [doi: 10.1111/j.1600-051X.2011.01832.x]

31. Axelsson P, Nyström B, Lindhe J. The long-term effect of a plaque control program on tooth mortality, caries and periodontal disease in adults. Results after 30 years of maintenance. J Clin Periodontol. 2004 Sep;31(9):749-57. [Medline: 15312097] [doi: 10.1111/j.1600-051X.2004.00563.x]

32. Armitage GC, Xenoudi P. Post-treatment supportive care for the natural dentition and dental implants. Periodontol 2000. 2016 Jun;71(1):164-84. [Medline: 27045436] [doi: 10.1111/prd.12122]

33. Lang NP, Wilson TG, Corbet EF. Biological complications with dental implants: their prevention, diagnosis and treatment. Clin Oral Implants Res. 2000;11 Suppl 1:146-55. [Medline: 11168263] [doi: 10.1034/j.1600-0501.2000.011S1146.x]

34. Lang NP, Tonetti MS. Periodontal risk assessment (PRA) for patients in supportive periodontal therapy (SPT). Oral Health Prev Dent. 2003;1(1):7-16. [Medline: 15643744]

35. Tonetti MS, Chapple IL, Jepsen S, Sanz M. Primary and secondary prevention of periodontal and peri-implant diseases: Introduction to, and objectives of the 11th European Workshop on Periodontology consensus conference. J Clin Periodontol. 2015 Apr;42 Suppl 16:S1-4. [Medline: 25683242] [doi: 10.1111/jepe.12382] 


\section{To cite this article:}

Ramanauskaite A, Tervonen T.

The Efficacy of Supportive Peri-Implant Therapies in Preventing Peri-Implantitis and Implant Loss: a Systematic Review of the Literature

J Oral Maxillofac Res 2016;7(3):e12

URL: http://www.ejomr.org/JOMR/archives/2016/3/e12/v7n3e12.pdf

doi: $10.5037 /$ jomr.2016.7312

Copyright (C) Ramanauskaite A, Tervonen T. Published in the JOURNAL OF ORAL \& MAXILLOFACIAL RESEARCH (http://www.ejomr.org), 9 September 2016.

This is an open-access article, first published in the JOURNAL OF ORAL \& MAXILLOFACIAL RESEARCH, distributed under the terms of the Creative Commons Attribution-Noncommercial-No Derivative Works 3.0 Unported License, which permits unrestricted non-commercial use, distribution, and reproduction in any medium, provided the original work and is properly cited. The copyright, license information and link to the original publication on (http://www.ejomr.org) must be included. 